\title{
Penetuan Tema Ruang Terbuka Hijau Aktif Di Kota Malang Berdasarakan Preferensi Masyarakat
}

\author{
Bagiar Adla Satria dan Prananda Navitas \\ Jurusan Perencanaan Wilayah dan Kota, Fakultas Teknik Sipil dan Perencanaan \\ Institut Teknologi Sepuluh Nopember (ITS) \\ Jl. Arief Rahman Hakim, Surabaya 60111 Indonesia \\ e-mail:prananda@urplan.its.ac.id
}

\begin{abstract}
Abstrak-Kota Malang merupakan kota layak huni terbaik ketiga di Indonesia. Salah satu indikator tingkat kenyamanan suatu kota adalah ruang terbuka hijau berupa taman. Berdasarkan persepsi masyarakat di Kota Malang ketersediaan dan persebaran taman sudah terpenuhi secara baik, namun tingkat daya tarik dan kondisi taman dinilai masih belum optimal. Taman tematik di Kota Malang belum memiliki keterkaitan tema dengan bangunan di sekitarnya, serta kesesuaian aktivitas pengunjung taman. Kota Malang memiliki 4 taman yang belum dikembangkan dengan tema tertentu, sehingga diperlukan alternatif tema yang sesuai dengan karakteristik berdasarkan preferensi masyarakat. Metode yang digunakan adalah observasi lapangan dan wawancara lisan untuk mengidentifikasi karakteristik RTH aktif di Kota Malang. Wawancara dan penyebaran kuisioner untuk memperoleh preferensi masyarakat sekitar yang kemudian dianalisis menggunakan metode Delphi. Hasil yang diperoleh adalah tema RTH aktif yang sesuai dengan karakterisitik kondisi eksisting serta preferensi masyarakat di sekitar taman. Taman Alun-alun Tugu dikembangkan dengan tema ciri khas kota. Taman Cerme dikembangkan dengan tema sejarah/historis kawasan. Taman Slamet dikembangkan dengan tema kesehatan. Taman Mojolangu dikembangkan dengan tema olahraga.
\end{abstract}

Kata Kunci- Preferensi Masyarakat, Ruang Terbuka Hijau Publik, Taman Tematik.

\section{PENDAHULUAN}

SALAH satu upaya penting dalam mewujudkan masyarakat yang berkelanjutan adalah dengan cara menciptakan greening the city yang salah satu refleksinya adalah adanya taman. Taman merupakan perwujudan dari greening city untuk menumbuhkan keterikatan sosial yang tinggi [1]. Hasil survey mengenai Most Liveable City di Indonesia didapatkan bahwa $41 \%$ responden menyatakan jumlah RTH taman di Kota Malang sudah tercukupi. RTH taman yang berfungsi sebagai salah satu fasilitas aktivitas sosial dinyatakan sudah terpenuhi 91\% secara kuantitas, serta 57\% secara kualitas. Parameter yang digunakan dalam menentukan kuantitas adalah ketersediaan jumlah dan persebaran fasiltas, sedangkan untuk kualitas dilihat berdasarkan tingkat daya tarik dan kondisi fasilitas [2]. Berdasarkan permasalahan tersebut dapat disimpulkan keberadaan taman di Kota Malang masih dirasa kurang menonjolkan fungsinya sebagai tempat aktivitas sosial secara kualitas.

Salah satu rencana penyediaan dan pemanfaatan RTH di
Kota Malang adalah mengisi dan memelihara taman-taman kota yang sudah ada dengan sebaik-baiknya. Pengembangan RTH yang dilakukan harus sesuai dengan prinsip fungsi pokok RTH berdasarkan karakteristik masing-masing lokasi [3]. Taman yang dibuat dengan memunculkan karakter tertentu dalam suatu tema sebagai ciri khas/tengeran dapat menjadi identitas kawasan. Taman tematik dapat berfungsi sebagai sarana pertukaran ide, pusat penelitan dan pengembangan produk kreatif [4].

Kota Malang memiliki 10 lokasi RTH aktif berupa taman. Sejumlah taman tersebut sudah dikembangkan menjadi taman tematik, yaitu antara lain: Taman Trunojoyo dan Taman Ronggowarsito dengan tema Taman Cerdas; Taman Merbabu dengan tema Taman Keluarga; serta Taman Merjosari dengan tema Taman Kota Layak Anak. Selain itu, terdapat 2 taman yang sedang dikembangkan sebagai taman tematik, yaitu Taman Alun-Alun Merdeka dengan tema Taman Air Mancur Menari; dan Taman Kendedes dengan tema Taman Topeng yang direncanakan akan selesai pada tahun 2015 [5]. Keberadaan taman-taman tematik di Kota Malang masih belum terintegrasi dengan lingkungan sekitar. Hal tersebut dapat dilihat keterkaitan tema yang dimiliki terhadap bangunan yang berada disekitarnya, serta kesesuaian aktivitas pengunjung taman [6].

Berdasarkan permasalahan penentuan tema RTH aktif di Kota Malang, maka diperlukan penelitian mengenai penentuan tema ruang terbuka hijau aktif yang sesuai dengan karakteristik berdasarkan preferensi masyarakat. Penentuan tema suatu taman perlu dilakukan untuk menciptakan taman tematik yang terintegrasi dengan lingkungan di sekitarnya. Penelitian ini diharapkan dapat memberikan alternatif tema ruang terbuka hijau aktif yang sesuai dengan karakteristik yang dimiliki suatu taman.

\section{II.METODE PENELITIAN}

\section{A. Variabel}

Penelitian ini menggunakan pustaka yang berkaitan dengan teori ruang terbuka hijau publik. Teori lain yang mendukung penelitian ini adalah kriteria dan faktor dalam penentuan tema taman. Berikut ini merupakan variabel dan definisi operasional yang digunakan pada penilitan ini. 
Tabel 1.

Variabel Penelitian

\begin{tabular}{|c|c|c|c|}
\hline No & Indikator & Variabel & Definisi Operasional \\
\hline 1 & $\begin{array}{c}\text { Fungsi } \\
\text { Taman } \\
\text { (Kuantitas) }\end{array}$ & $\begin{array}{l}\text { Kondisi } \\
\text { Vegetasi }\end{array}$ & $\begin{array}{l}\text { Luas minimum untuk taman } \\
\text { tematik (m2) } \\
\text { Prosentase luas tutupan lahan } \\
\text { hijau (\%) }\end{array}$ \\
\hline 2 & $\begin{array}{c}\text { Fungsi } \\
\text { Taman } \\
\text { (Kualitas) }\end{array}$ & $\begin{array}{l}\text { Aktivitas } \\
\text { Taman }\end{array}$ & $\begin{array}{c}\text { Jenis kegiatan dan kategori } \\
\text { pengunjung taman pada pagi- } \\
\text { malam hari } \\
\text { Ketersediaan fasilitas penunjang } \\
\text { keamanan } \\
\text { Ketersediaan fasilitas penunjang } \\
\text { kenvamanan }\end{array}$ \\
\hline 3 & Lokasi & $\begin{array}{l}\text { Aksesibilitas } \\
\text { Jarak } \\
\text { Terhadap } \\
\text { Landmark }\end{array}$ & $\begin{array}{c}\text { Jenis jalan di sekitar taman } \\
\text { Jarak dengan landmark Kota } \\
\text { Malang, yaitu monumen tugu dan } \\
\text { alun-alun }(\mathrm{km})\end{array}$ \\
\hline \multirow{3}{*}{4} & \multirow{3}{*}{$\begin{array}{l}\text { Potensi } \\
\text { Wilayah } \\
\text { Sektiar }\end{array}$} & Ekonomi & $\begin{array}{c}\text { Keberadaan sarana perdagangan } \\
\text { dan jasa, serta kegiatan } \\
\text { pemenuhan kebutuhan barang } \\
\text { dan jasa }\end{array}$ \\
\hline & & Pariwisata & $\begin{array}{c}\text { Keberadaan sarana rekreasi, serta } \\
\text { daya tarik lokasi sebagai tujuan } \\
\text { rekreasi masyarakat }\end{array}$ \\
\hline & & Historis & $\begin{array}{c}\text { Keberadaan bangunan bersejarah } \\
\text { dan nilai historis kawasan }\end{array}$ \\
\hline
\end{tabular}

Sumber: Penulis, 2015

\section{B. Metode Pengumpulan Data}

Data yang digunakan pada penelitian ini terdiri atas data primer dan sekunder, dimana data primer diperoleh berdasarkan pengamatan secara langsung (observasi), wawancara serta kuesioner. Sedangkan data sekunder diperoleh dari dokumen-dokumen instansi terkait, yaitu Dinas Kebersihan dan Pertamanan Kota Malang, serta literatur dari penelitian terkait.

\section{C.Penentuan Tipologi Tema}

Berdasarkan fungsi ruang terbuka hijau sebagai nilai ekologis, sosial-budaya, ekonomi dan estetika, taman dapat diklasifikasikan menjadi 3 jenis [7], yaitu antara lain:

Tabel 2.

Klasifikasi Ruang Terbuka Hijau

\begin{tabular}{cl}
\hline \hline Klasifikasi & \multicolumn{1}{c}{ Keterangan } \\
\hline Taman Sejarah & $\begin{array}{l}\text { Berfungsi sebagai simbol sejarah pada suatu kawasan } \\
\text { yang terjadi pada masa lalu }\end{array}$ \\
Taman Edukatif & $\begin{array}{l}\text { Berfungsi sebagai sarana rekreasi masyarakat, baik } \\
\text { individu maupun kelompok }\end{array}$ \\
Taman & $\begin{array}{l}\text { Berfungsi sebagai simbol sejarah pada suatu kawasan } \\
\text { Rekreatif }\end{array}$ \\
\hline
\end{tabular}

Sumber: Purnomohadi, 2006.

Pada tahap ini dilakukan kajian studi kasus taman tematik di Kota Surabaya dan Kota Bandung yang memiliki tingkat keberhasilan cukup baik. Output kajian ini adalah tipologi tema yang disesuaikan dengan karakteristik masing-masing taman tematik terhadap fungsi pokok ruang terbuka hijau.

\section{Mengidentifikasi karakteristik ruang terbuka hijau aktif di Kota Malang}

Dalam mengidentifikasi karakteristik ruang terbuka hijau di Kota Malang digunakan teknik empirical descriptive analysis dan theoritical descriptive analysis. Empirical descriptive analysis digunakan untuk mengidentifikasi secara intensif terhadap perilaku, karakteristik, maupun data eksisting lainnya. Theoritical descriptive analysis dilakukan untuk memperkuat hasil kondisi eksisting dengan teori, kebijakan, serta hasil penelitian terkait [8]. Pada tahap ini terdapat 4 yang akan di identifikasi berdasarkan karakterisik masing-masing objek penelitian. Output yang dihasilkan dari teknik analisis ini adalah karakteristik taman yang akan menjadi input data pada analisis selanjutnya.

\section{E. Menentukan tema ruang terbuka hijau aktif di Kota Malang berdasarkan preferensi masyarakat}

Teknik analisis yang digunakan dalam menganalisis preferensi masyarakat terhadap penentuan tema pada masingmasing taman adalah metode Delphi. Teknik ini dapat menggali pemahaman yang mendalam dan menyeluruh, serta bertujuan untuk mendapatkan hasil yang konsensus [9]. Responden yang dipilih merupakan pakar yang paham terhadap permasalahan penelitian, yaitu masyarakat yang berada di radius skala pelayanan taman sejauh 300 meter [10]. Untuk mendapatkan responden yang dapat dianggap sebagai pakar ditentukan dengan kriteria responden.

\section{HASIL DAN DISKUSI}

\section{A. Penentuan Tipologi Tema}

Dari 31 taman tematik yang berada di Kota Surabaya dan Kota Bandung dapat diklasifikasikan menjadi beberapa tipologi tema yang ditentukan berdasarkan karakteristik eksisting taman sesuai dengan fungsi utama RTH, yaitu Taman Sejarah, Edukatif, dan Rekreatif. Pengelompokan jenis tipologi dilakukan secara bertahap, sehingga dapat ditarik alternatif tema yang sesuai dengan karakteristik masing-masing taman tematik. Berikut ini merupakan hasil kajian tipologi tema taman-taman tematik.

Tabel 3 .

Tipologi Tema

\begin{tabular}{|c|c|c|}
\hline $\begin{array}{l}\text { Klasifikasi } \\
\text { RTH }\end{array}$ & Tema & Keterangan \\
\hline $\begin{array}{l}\text { Taman } \\
\text { Sejarah }\end{array}$ & $\begin{array}{c}\text { Sejarah/historis } \\
\text { kawasan }\end{array}$ & $\begin{array}{l}\text { Memiliki nilai sejarah/historis di } \\
\text { sekitar kawasan }\end{array}$ \\
\hline Taman & Aktivitas rutin & $\begin{array}{l}\text { Kegiatan yang sering dilakukan oleh } \\
\text { masyarakat (pengunjung) }\end{array}$ \\
\hline
\end{tabular}




\begin{tabular}{|c|c|c|}
\hline \multirow[t]{3}{*}{ Edukatif } & Olahraga & $\begin{array}{l}\text { Aktivitas yang berhubungan dengan } \\
\text { kegiatan olahraga }\end{array}$ \\
\hline & Minat Khusus & $\begin{array}{l}\text { Aktivitas yang berhubungan dengan } \\
\text { hobi dan kegemaran }\end{array}$ \\
\hline & Kesehatan & $\begin{array}{l}\text { Terdapat sarana belajar tentang } \\
\text { kesehatan dan lingkungan }\end{array}$ \\
\hline \multirow[t]{2}{*}{$\begin{array}{l}\text { Taman } \\
\text { Rekreatif }\end{array}$} & $\begin{array}{l}\text { Ikon/simbol khusus } \\
\text { dalam taman }\end{array}$ & $\begin{array}{l}\text { Keberadaan suatu ikon/simbol } \\
\text { berupa objek penting dalam taman }\end{array}$ \\
\hline & Ciri khas kota & $\begin{array}{l}\text { Sebagai identitas suatu kota, secara } \\
\text { sosial-budaya maupun lingkungan }\end{array}$ \\
\hline
\end{tabular}

Sumber: Penulis, 2015.

B. Mengidentifikasi karakteristik ruang terbuka hijau aktif di Kota Malang

Dari keempat taman yang telah di observasi dapat diidentifikasi berdasarkan karakteristik suatu taman dilihat dari aspek internal maupun eksternal. Aspek internal dapat dilihat melalui fungsi taman secara kuantitas dan kualitas, sedangkan aspek eksternal dilihat berdasarkan keberadaan lokasi dan potensi wilayah sekitar taman.

Tabel 4.

Identifikasi Karakteristik Ruang Terbuka Hijau Aktif di Kota Malang

\begin{tabular}{|c|c|c|c|c|}
\hline \multirow{2}{*}{ Variabel } & \multicolumn{4}{|c|}{ Taman } \\
\hline & Alun-alun Tugu & Cerme & Slamet & Mojolangu \\
\hline Luas Taman $\left(\mathrm{m}^{2}\right)$ & 10.923 & 1.825 & 2.852 & 16.695 \\
\hline Kondisi Vegetasi & $50-60 \%$ & $50-60 \%$ & $60-70 \%$ & $60-70 \%$ \\
\hline Aktivitas Taman & $\begin{array}{l}\text { - Relaksasi } \\
\text { - Minat khusus } \\
\text { - Ekonomi }\end{array}$ & $\begin{array}{l}\text { - Relaksasi } \\
\text { - Minat khusus }\end{array}$ & Relaksasi & $\begin{array}{ll}\text { - } & \text { Relaksasi } \\
\text { - } & \text { Olahraga }\end{array}$ \\
\hline Keamanan & $\begin{array}{l}\text { - Lampu taman } \\
\text { - Papan informasi }\end{array}$ & - Kantor pengelola & $\begin{array}{l}\text { - Pos penjaga } \\
\text { - Papan } \\
\text { peringataan }\end{array}$ & $\begin{array}{l}\text { - Lampu taman } \\
\text { - Lahan parkir }\end{array}$ \\
\hline Kenyamanan & $\begin{array}{ll}\text { - } & \text { Jalur pejalan kaki } \\
\text { - } & \text { Area duduk } \\
\text { - } & \text { Fasilitas } \\
& \text { kebersihan } \\
\text { - } & \text { Monumen tugu } \\
\text { - } & \text { Kolam bunga } \\
& \text { teratai }\end{array}$ & $\begin{array}{ll}\text { - } & \text { Jalur pejalan kaki } \\
\text { - } & \text { Fasilitas } \\
& \text { kebersihan } \\
\text { - } & \text { Kolam air }\end{array}$ & $\begin{array}{l}\text { - Jalur pejalan kaki } \\
\text { - Area duduk } \\
\text { - Fasilitas } \\
\text { kebersihan }\end{array}$ & $\begin{array}{l}\text { - Jalur pejalan kaki } \\
\text { - Area duduk } \\
\text { - Fasilitas kebersihan } \\
\text { - Gazebo } \\
\text { - Batu refleksi } \\
\text { - Jogging track }\end{array}$ \\
\hline Aksesibilitas & Arteri sekunder & Lokal sekunder & Lokal sekunder & Lokal primer \\
\hline Jarak terhadap landmark $(\mathrm{km})$ & 0 & 1,2 & 1,3 & 4,75 \\
\hline Ekonomi & Ada & Tidak ada & Tidak ada & Tidak ada \\
\hline Pariwisata & Ada & Ada & Tidak ada & Tidak ada \\
\hline Historis & Ada & Ada & Tidak ada & Tidak ada \\
\hline
\end{tabular}

Sumber: Penulis, 2015.

Berikut ini merupakan penjelasan dari setiap variabel yang menentukan karakteristik suatu taman.

\section{Luas Taman}

Rentang luas taman yang dimiliki dari 4 objek penelitian adalah antara $2.000-16.000 \mathrm{~m} 2$, dimana seluruh taman dinilai sudah memnuhi standar kebutuhan luas untuk dikembangkan sebagai taman tematik. Sehingga seluruh objek penelitian dapat dikembangkan sebagai taman tematik secara kuantitas di dalam taman tersebut.

\section{Kondisi Vegetasi}

Rentang kondisi tutupan lahan hijau dari 4 objek penelitian adalah $50-70 \%$, dimana kententuan minimal vegetasi dalam taman sebesar 40-60\%. Sehingga dalam pengembangan sebagai taman tematik, seluruh objek penelitian tetap memperhatikan nilai ekologis suatu ruang terbuka hijau publik.

\section{Aktivitas Taman}

Berdasarkan jenis kegiatan dan kategori pengunjung taman dapat dilihat karakteristik yang sesuai dengan suatu taman. Taman Alun-alun Tugu memliki jenis kegiatan yang beragam, yaitu aktivitas relaksasi, minat khusus, dan ekonomi. Taman Slamet memiliki potensi aktivitas relaksasi yang cukup baik dilihat berdasarkan kondisi taman yang mendukung. Sedangkan taman Cerme dan Mojolangu hanya memiliki aktivitas relaksasi, hal tersebut dikarenakan kondisi taman yang masih belum dikembangkan secara menyeluruh. Berdasarkan kategori pengunjung, rata-rata pengunjung taman adalah anak-anak, pemuda, serta keluarga. Di sisi lain, taman Slamet terdapat pengunjung khusus yaitu orang lanjut usia (lansia).

\section{Keamanan}

Ketersediaan fasilitas penunjang keamanan taman menjadi hal penting yang harus diperhatikan dalam pengembangan taman tematik. Fasilitas yang diperlukan antara lain, pos penjagaan, lampu taman dan kantor pengelola. Dalam hal ini hanya taman Alun-alun Tugu dan Slamet yang terpenuhi secara baik dilihat dari keberadaan fasilitas keamanan di dalam taman. Sedangkan pada taman Cerme dan Mojolangu belum terpenuhi secara baik, sehingga tingkat keamanan di dalam taman masih diragukan. Hal tersebut dikarenakan kedua taman ini belum sepenuhnya terbangun, sehingga perlu penyediaan fasilitas penunjang keamanan taman untuk dapat menjadi suatu taman tematik.

\section{Kenyamanan}

Ketersediaan fasilitas penunjang kenyamanan taman merupakan kewajiban suatu taman dalam mengakomodir 
berbagai aktivitas pengunjung taman. Dari keempat taman, dapat dilihat bahwa sudah memiliki fasilitas penunjang kenyamanan yang cukup lengkap, secara umum yaitu jalur pejalan kaki, area duduk, fasilitas kebersihan serta vegetasi taman. Namun sebagai sebuah taman tematik, fasilitas yang ada harus dikembangkan secara selaras agar meningkatkan ciri khas yang dimiliki taman tersebut. Sehingga seluruh taman perlu menambahkan beberapa fasilitas yang disesuiakan dengan tema pengambangan yang akan dilakukan nantinya, misalnya area aktivitas rutin dan area terbatas berjualan.

\section{Aksesibilitas}

Kemudahan pengunjung untuk mencapai suatu taman perlu diperhatikan secara khusus, dimana jenis jalan yang berada di sekitar taman dapat meningkatkan aksesibilitas yang ada. Taman Alun-alun Tugu memiliki tingkat aksesibilitas paling baik, yaitu dilalui oleh jenis jalan arteri. Sehingga pengunjung dapat mencapai taman tersebut dengan mudah. Sedangkan pada taman Cerme, Slamet dan Mojolangu yang dilalui oleh jalan lokal, dikarenakan lokasinya yang berada di kawasan permukiman kurang diketahui oleh pengunjung.

\section{Jarak Terhadap Landmark}

Kedekatan dengan landmark yang dimiliki Kota Malang, yaitu monumen tugu dan alun-alun kota menjadi salah satu penentuan tema taman tematik. Dalam hal ini, taman tematik dapat mengikuti keselarasan yang dimiliki oleh landmark tersebut. Taman Alun-alun Tugu yang merupakan landmark Kota Malang menjadi alternatif penentuan tema sebagai ciri khas Kota Malang. Sedangkan pada taman Cerme dan Slamet memiliki jarak terhadap landmark relatif jauh, sehinggan penentuan tema tidak bisa diselaraskan. Jarak terjauh dimiliki oleh taman Mojolangu, dimana tidak terdapat keterkaitan dengan ciri khas Kota Malang.

\section{Ekonomi}

Kegiatan ekonomi menjadi potensi wilayah di sekitar taman merupakan jenis aktivitas yang berkaitan dengan pemenuhan kebutuhan barang dan jasa. Dalam hal ini, potensi ekonomi hanya terdapat pada taman Alun-alun Tugu, yaitu berupa aktivitas pedagang kaki lima yang ada pada malam hari. Sedangkan pada taman Cerme, Slamet dan Mojolangu tidak memiliki potensi ekonomi di sekitarnya.

\section{Pariwisata}

Keberadaan sarana rekreasi dapat menjadi daya tarik tersendiri bagi pengunjung taman. Dalam hal ini, Taman Alun-alun Tugu dan Cerme memiliki potensi sebagai sarana rekreasi, yaitu dilihat dari monumen tugu sebagai objek wisata kota dan bangunan hotel sebagai sarana penunjang. Sedangkan pada taman Slamet dan Mojolangu tidak memiliki daya tarik khusus sebagai objek wisata.

\section{Historis}

Pontesi sejarah kawasan di sekitar taman dapat menjadi salah satu alternatif penentuan tema taman. Dengan memperhatikan tersebut, suatu taman dapat dikembangkan sebagai sarana edukasi dan penanda suatu kejadian bersejarah. Dalam hal ini, Taman Alun-alun Tugu dan
Cerme memiliki potensi sejarah, dikarenakan terdapat objek yang sudah ada sejak zaman kolonial Belanda. Sedangkan taman Slamet dan Mojolangu tidak memiliki nilai historis kawasan yang cukup signifikan di sekitarnya.

\section{Menentukan tema ruang terbuka hijau aktif di Kota} Malang berdasarkan preferensi masyarakat

Analisis ini dilakukan melalui penyebaran kuisoner kepada masyarakat yang tinggal/menetap dalam radius pelayanan objek penelitian. Pertanyaan kuisoner terbagi dalam dua jenis, yaitu eksplorasi pertanyaan secara umum untuk mendapatkan karakteristik taman yang belum teridentifikasi, serta penentuan kesesuain tema taman pada objek penelitian menggunakan analisis Delphi.

\section{Taman Alun-alun Tugu}

Penggunaan lahan di sekitar taman ini didominasi oleh jenis kegiatan fasilitas umum berupa kantor pemerintahan dan sekolah. Adapun berbagai jenis kegitan perdagangan dan jasa sebagai pusat kegiatan ekonomi di Kota Malang.

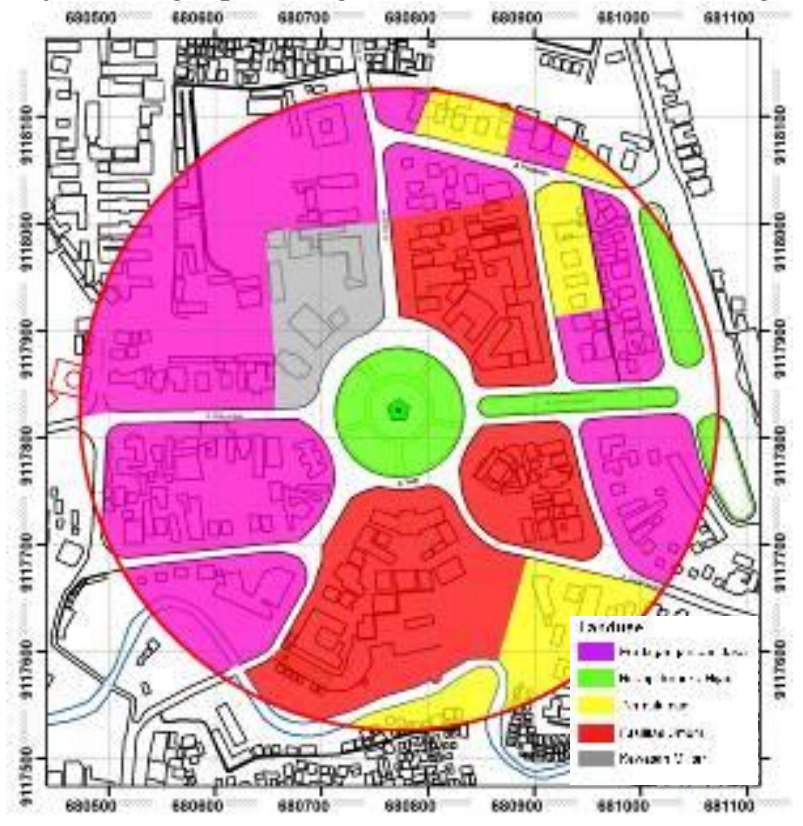

Gambar 1. Peta Penggunaan Lahan Taman Alun-alun Tugu

Dari 7 responden didapatkan hasil konsensus penentuan tema yang sesuai adalah sejarah/historis kawasan dan ciri khas kota. Hal tersebut dikarenakan pada kawasan ini memiliki nilai historis Kota Malang dan keberadaan monumen tugu yang cukup dikenal banyak orang.

Dilihat berdasarkan kondisi eksisting taman, tema yang lebih sesuai untuk dikembangkan adalah ciri khas kota, karena lokasi ini menjadi salah satu landmark di Kota Malang.

\section{Taman Cerme}

Penggunaan lahan di sekitar taman ini didominasi oleh jenis kegiatan permukiman dan sebagian perdagangan dan jasa. 


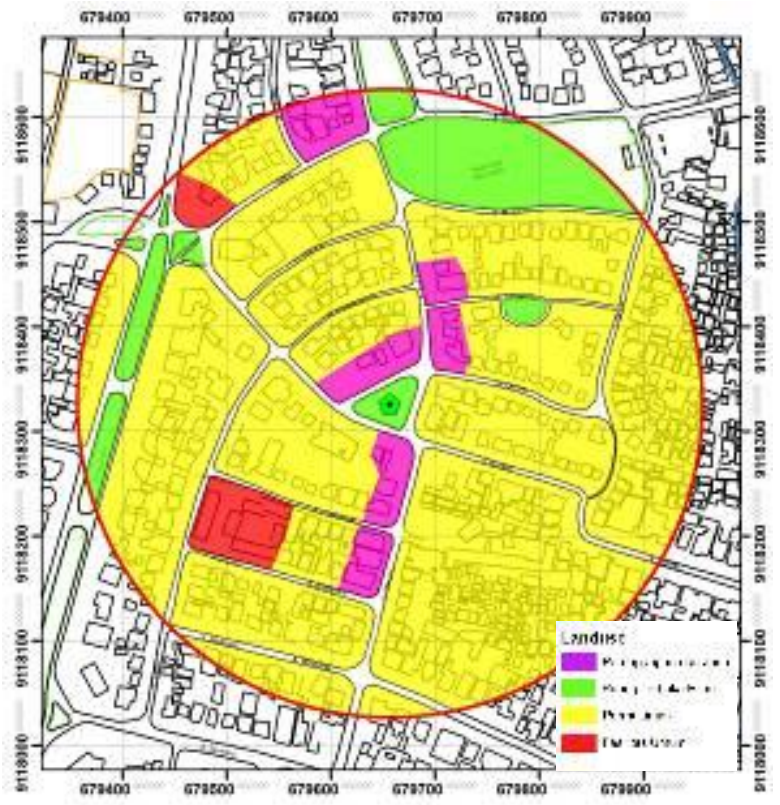

Gambar 2. Peta Penggunaan Lahan Taman Cerme

Dari 30 responden didapatkan hasil konsensus penentuan tema yang sesuai adalah sejarah/historis kawasan dan ikon/simbol taman. Hal tersebut dikarenakan keberadaan bangunan cagar budaya berupa hotel dan keberadaan kolam air di dalam taman yang menjadi pusat perhatian.

Dilihat berdasarkan kondisi eksisting taman, tema yang lebih sesuai untuk dikembangkan adalah sejarah/historis kawasan, karena potensi wilayah sekitar yang paling dominan adalah historis. Di samping itu aktivitas minat khusus dapat dikembangkan sesuai dengan nilai sejarah yang dimiliki oleh bangunan cagar budaya tersebut.

\section{Taman Slamet}

Penggunaan lahan di sekitar taman ini didominasi oleh jenis kegiatan permukiman, dimana terletak pada lingkungan perumahan.

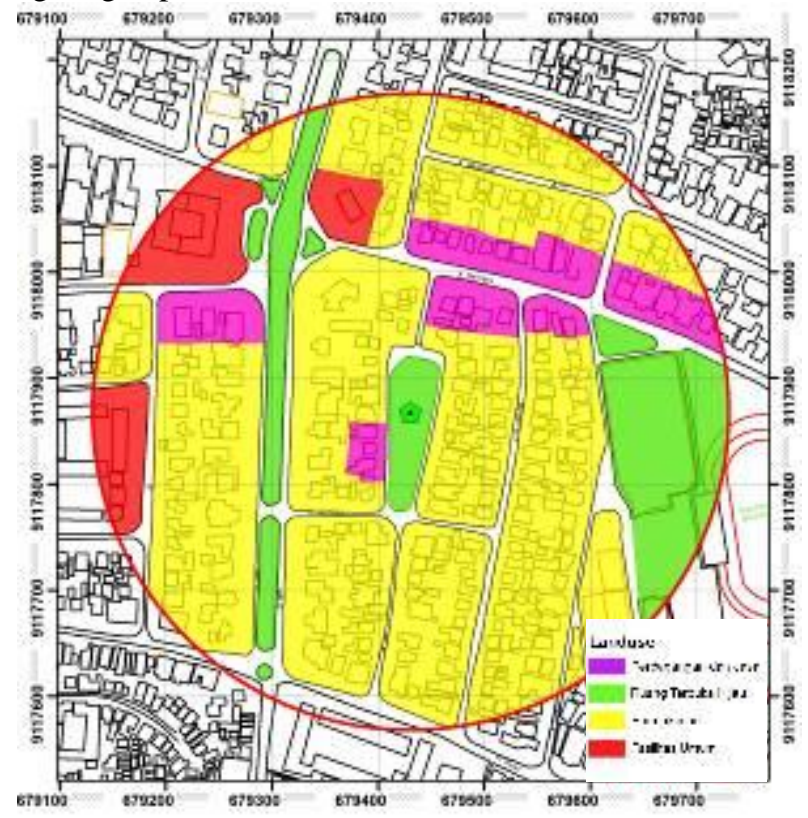

Gambar 3. Peta Penggunaan Lahan Taman Slamet

Dari 19 responden didapatkan hasil konsensus penentuan tema yang sesuai adalah aktivitas rutin dan kesehatan. Hal tersebut dikarenakan adanya kegiatan secara berkala oleh masyarakat lanjut usia (lansia) dan kondisi lingkungan yang mendukung untuk fasilitas penunjang kesehatanDilihat berdasarkan kondisi eksisting taman, tema yang lebih sesuai untuk dikembangkan adalah kesehatan, karena adanya aktivitas rutin berupa kegiatan relaksasi di dalam taman. Hal tersebut ditunjang dengan kondisi taman yang cukup nyaman dan jauh dari keramaian, serta luasan tutupan lahan hijau yang lebih dominan.

\section{Taman Mojolangu}

Penggunaan lahan di sekitar taman ini didominasi oleh jenis kegiatan permukiman, serta areal persawahan dan lahan kosong.

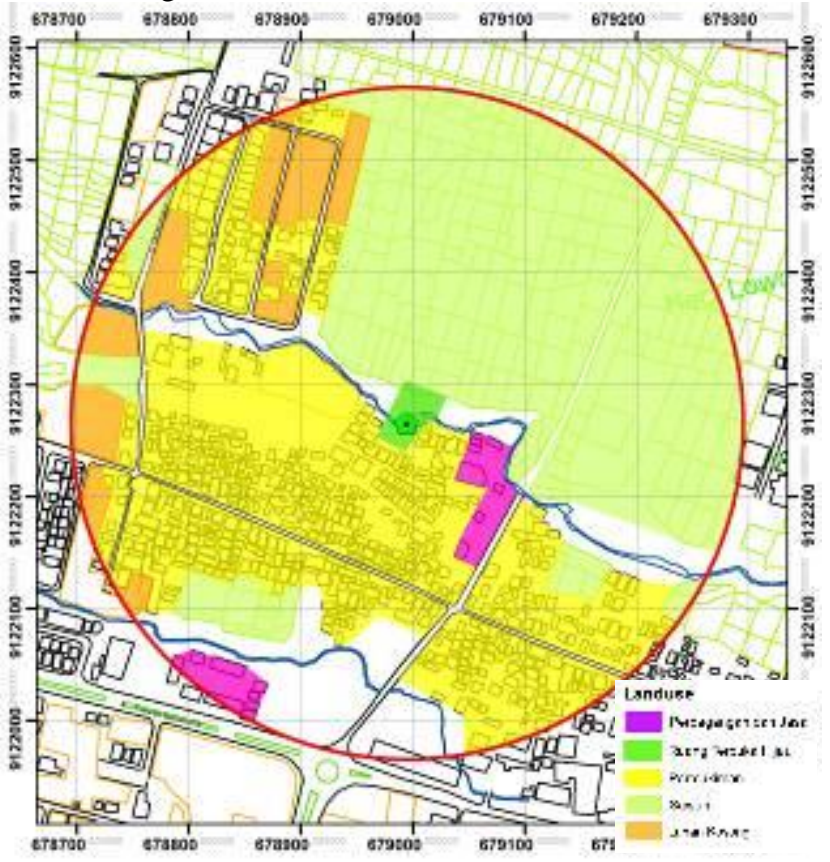

Gambar 4. Peta Penggunaan Lahan Taman Mojolangu

Dari 30 responden didapatkan hasil konsensus penentuan tema yang sesuai adalah tema olahraga dan minat khusus. Hal tersebut dikarenakan terdapat fasilitas olahraga berupa lapangan futsal di sekitar taman dan kebiasaan masyarakat yang gemar bercocok tanam terlihat dari dominasi wilayah berupa areal persawahan.

Dilihat berdasarkan kondisi eksisting taman, tema yang lebih sesuai untuk dikembangkan adalah olahraga, karena adanya aktivitas rutin pada taman ini adalah relaksasi dan olahraga. Di samping itu taman ini memiliki luasan yang cukup besar jika digunakan sebagai aktifitas olahraga.

\section{KESIMPULAN}

Berdasarkan pembahasan yang telah dilakukan, maka dapat disimpulkan mengenai penentuan tema ruang terbuka hijau aktif di Kota Malang. Pada masing-masing objek penelitian dapat ditentukan tema taman sebagai berikut:

\section{Taman Alun-alun Tugu}

Berdasarkan hasil identifikasi karakteristik taman eksisting, pada objek penelitian ini dapat dikembangkan menjadi taman tematik dengan mempertimbangkan monumen tugu sebagai landmark Kota Malang. Serta terdapat potensi ekonomi, pariwisata dan sejarah di 
sekitar kawasan. Taman ini dapat dikembangkan dengan tema ciri khas kota, karena adanya monumen tugu yang sudah cukup dikenal oleh masyarakat luas.

\section{Taman Cerme}

Berdasarkan hasil identifikasi karakteristik taman eksisting, pada objek penelitian ini dapat dikembangkan menjadi taman tematik dengan mempertimbangkan bangunan cagar budaya yang memiliki potensi sejarah. Namun masih perlu dilakukan peningkatan fasilitas penunjang keamanan dan kenyamanan taman. Taman ini dapat dikembangkan dengan tema sejarah/historis kawasan, karena adanya bangunan cagar budaya berupa hotel.

\section{Taman Slamet}

Berdasarkan hasil identifikasi karakteristik taman eksisting, pada objek penelitian ini dapat dikembangkan menjadi taman tematik dengan mempertimbangkan kondisi vegetasi dan suasana nyaman. Taman ini dapat dikembangkan dengan tema kesehatan, karena kondisi lingkungan yang mendukung untuk fasilitas penunjang kesehatan, serta adanya aktivitas rutin berupa senam kesehatan yang dilakukan oleh masyarakat setempat.

\section{Taman Mojolangu}

Berdasarkan hasil identifikasi karakteristik taman eksisting, pada objek penelitian ini dapat dikembangkan menjadi taman tematik. Namun perlu dilakukan pembangunan lebih lanjut agar menjadi taman tematik yang memiliki ciri khas. Taman ini dapat dikembangkan dengan tema olahraga, karena terdapat aktivitas rutin berupa kegiatan olahraga, serta keberadaan fasilitas lapangan futsal yang berada di sekitar taman. Di samping itu luasan taman yang cukup besar dapat dimanfaatkan sebagai sarana kegiatan olahraga.

\section{DAFTAR PUSTAKA}

[1] Budihardjo, Eko dan Sujarto, Djoko. 2005. Kota Berkelanjutan (Sustainable City). Bandung: P.T Alumni.

[2] Ikatan Ahli Perencana. 2014. Draft Kajian Most Liveable City Index 2014 Kota Malang. Jakarta.

[3] Rencana Tata Ruang Wilayah Kota Malang Tahun 2010-2030

[4] Landry, Charles. 2008. The Creative City: A Toolkit for Urban Innovators. London: Earthscan.

[5] Buku Profil Bidang Pertamanan Pemerintah Kota Malang Tahun 2014.

[6] Surya Malang. 2 Maret 2015. Baru Sebatas Indah, Harusnya Terintegrasi Dengan Lingkungan. http://suryamalang.tribunnews.com/2015/03/02/baru-sebatas-indahseharusnya-terintegrasi-dengan-lingkungan (diakses tanggal 9 Maret 2015)

[7] Purnomohadi, Ning. 2006. Ruang Terbuka Hijau Sebagai Unsur Utama Dalam Tata Ruang Kota. Dikjen Penataan Ruang, Departemen Pekerjaan Umum: Jakarta.

[8] Arikunto, S. 2006. Prosedur Penelitian Suatu Pendekatan Praktik. Jakarta: Rineka Cipta.

[9] Sudjana. 2000. Metode Statistik. Tarsito: Bandung.

[10] Peraturan Menteri Pekerjaan Umum Nomor: 05/PRT/M/2008 